\title{
Distribution of the cladoceran Bosmina huaronensis Delachaux, 1918 and niche differentiation among populations from different biogeographic regions
}

\author{
Lourdes M. A. Elmoor-Loureiro
}

Laboratório de Biodiversidade Aquática, Universidade Católica de Brasília. QS 7, lote 1, sala M204. 71966-700. Taguatinga, DF, Brasil.E-mail: lourdes@ucb.br

\begin{abstract}
Described from a high-altitude lake in Peru, Bosmina huaronensis Delachaux, 1918 has been recorded in diverse kinds of water bodies in South and North America, suggesting that this species has high environmental tolerance and a wide niche breadth. The present study surveyed the occurrence records of $B$. huaronensis from 55 localities and, using multivariate analysis, investigated the niche differentiation among populations from different biogeographic regions, based on altitude and seven climatic variables. The first two principal components (PC) explained $73 \%$ of the overall variance. $\mathrm{PC} 1$ was related to annual mean temperature, precipitation of driest quarter, and annual precipitation. PC2 was related to temperature seasonality and precipitation of wettest quarter. The PCA diagram showed three population groups, occupying different climate niches: (1) tropical highlands; (2) Neotropical lowlands; (3) temperate zones of both hemispheres. These results point to the need for further evaluation of these populations under morphological, genetic and ecological aspects.
\end{abstract}

Key words: Anomopoda, biogeography, Bosminidae, climatic variables

\section{INTRODUCTION}

Bosmina huaronensis Delachaux, 1918 is a member of the zooplanktonic community from water bodies in a different trophic state (e.g. Menu-Marque and Marinoni, 1986; Zanata, 2005; Di Genaro, 2010). Described from a high-altitude lake in Peru (Lake Huaron, about $4,640 \mathrm{~m}$ a.s.1.), it has been recorded in diverse kinds of water bodies in South and North America (e.g. Paggi, 1979; De Melo and Hebert, 1994). In the South American tropical zone, Green (1995) only found B. huaronensis in lakes placed above 3,800 $\mathrm{m}$ a.sl. However, many records include South American ponds, lakes, reservoirs, and rivers in subtropical and temperate lowlands (e.g. Paggi, 1979; Velho et al., 2000; Serafim Junior et al., 2006; Rocha et al., 2011).

The niche is considered an abstract multidimensional space, in which a set of biotic and abiotic conditions allow a species to maintain a viable population (Hutchinson, 1957; Schnitzler et al., 2012). Considering the variety of water bodies where $B$. huaronensis occurs - in terms of geographic location, size, water flow, and trophic state - this species seems to have high tolerance and a wide niche breadth. On the other hand, it could be hypothesized that dominant clones in different populations differ in their ecological niche.

Principal Component Analysis (PCA) is considered a useful tool for investigating niche differences, as it provides the means to explain the variance magnitudes related to environmental variables, which represent the environmental niche (Janžekovič and Novak 2012). For this purpose, it is desirable to have a robust data set, including as many environmental variables as possible, a condition not reached for B. huaronensis, as for many other organisms. 
In the absence of a more complete data set, altitude and climatic variables, now easily available from global climate databases, have been used for niche differentiation studies for a variety of organisms and objectives (e.g. Knouft et al., 2006; Ibarra-Cerdeña et al., 2009; Batista and Gurgel-Gonçalves, 2009;
Kamilar and Muldoon, 2010; Giannini et al., 2011; Schnitzler et al., 2012).

The present study aims to survey the occurrence records of $B$. huaronensis and investigate the niche differentiation among populations from different biogeographic regions, based on altitude and climatic variables.

Table 1. Occurrence records of Bosmina huaronensis and their biogeographic classification, using Morrone’s criteria (2006).

\begin{tabular}{|c|c|c|c|c|}
\hline & Occurrence record & Coordinates & Biogeographic Classification & Source \\
\hline$\overline{\mathrm{AN} 01}$ & Pond in Amarillo, Texas, USA & $35.218^{\circ} \mathrm{N}, 101.852^{\circ} \mathrm{W}$ & Neartic region & De Melo and Hebert 1994 \\
\hline AN02 & Lyman Lake, Arizona, USA & $34.364^{\circ} \mathrm{N}, 109.374^{\circ} \mathrm{W}$ & Neartic region & Waterflea.Org database \\
\hline AN03 & Santa Anna Reservoir, Hidalgo State, Mexico & $20.208^{\circ} \mathrm{N}, 98.208^{\circ} \mathrm{W}$ & Mexican transition zone & De Melo and Hebert 1994 \\
\hline AN04 & La Goleta, Mexico & $20.070^{\circ} \mathrm{N}, 99.556^{\circ} \mathrm{W}$ & Mexican transition zone & Global Barcode database \\
\hline AS01 & Lake Huaron, Peru & $11.030^{\circ} \mathrm{S}, 76.428^{\circ} \mathrm{W}$ & South-American transition zone & Delachaux, 1918 \\
\hline AS02 & Lake Junin, Peru & $11.024^{\circ} \mathrm{S}, 76.118^{\circ} \mathrm{W}$ & South-American transition zone & Valdivia-Villar, 1988 \\
\hline AS03 & Lake Arapa, Peru & $15.155^{\circ} \mathrm{S}, 70.109^{\circ} \mathrm{W}$ & South-American transition zone & Valdivia-Villar, 1988 \\
\hline AS04 & Lake Titicaca, Peru & $15.796^{\circ} \mathrm{S}, 69.383^{\circ} \mathrm{W}$ & South-American transition zone & Paggi, 1979 \\
\hline AS05 & Lake Titicaca, Bolivia & $16.225^{\circ} \mathrm{S}, 68.764^{\circ} \mathrm{W}$ & South-American transition zone & Uéno, 1967 \\
\hline AS06 & Pools in Cochabamba, Bolivia & $17.278^{\circ} \mathrm{S}, 66.213^{\circ} \mathrm{W}$ & South-American transition zone & Coronel et al., 2007 \\
\hline AS07 & Lake near Yala, Jujuy, Argentina & $24.113^{\circ} \mathrm{S}, 65.484^{\circ} \mathrm{W}$ & South-American transition zone & Paggi, 1979 \\
\hline AS08 & Lake Paranoá, Federal District, Brazil & $15.733^{\circ} \mathrm{S}, 47.882^{\circ} \mathrm{W}$ & Neotropical region & present study \\
\hline AS09 & Três Irmãos Reservoir, São Paulo, Brazil & $20.694^{\circ} \mathrm{S}, 51.100^{\circ} \mathrm{W}$ & Neotropical region & Zanata, 2005; Rocha et al., 2011 \\
\hline AS10 & Três Irmãos Reservoir, São Paulo, Brazil & $20.851^{\circ} \mathrm{S}, 50.555^{\circ} \mathrm{W}$ & Neotropical region & Rocha et al., 2011 \\
\hline AS11 & Nova Avanhandava Reservoir, S.Paulo, Brazil & $21.156^{\circ} \mathrm{S}, 50.139^{\circ} \mathrm{W}$ & Neotropical region & Zanata, 2005; Rocha et al., 2011 \\
\hline AS12 & Lake in Birigui, São Paulo, Brazil & $21.241^{\circ} \mathrm{S}, 50.397^{\circ} \mathrm{W}$ & Neotropical region & Rocha et al., 2011 \\
\hline AS13 & Promissão Reservoir, São Paulo, Brazil & $21.320^{\circ} \mathrm{S}, 49.737^{\circ} \mathrm{W}$ & Neotropical region & Zanata, 2005; Rocha et al., 2011 \\
\hline AS14 & Bariri Reservoir, São Paulo, Brazil & $22.168^{\circ} \mathrm{S}, 48.731^{\circ} \mathrm{W}$ & Neotropical region & Rocha et al., 2011 \\
\hline AS15 & Lake Areia que Canta, São Paulo, Brazil & $22.315^{\circ} \mathrm{S}, 48.052^{\circ} \mathrm{W}$ & Neotropical region & Rocha et al., 2011 \\
\hline AS16 & Barra Bonita Reservoir, São Paulo, Brazil & $22.529^{\circ} \mathrm{S}, 48.523^{\circ} \mathrm{W}$ & Neotropical region & Zanata, 2005; Rocha et al., 2011 \\
\hline AS17 & Garças Reservoir, São Paulo, Brazil & $23.647^{\circ} \mathrm{S}, 46.624^{\circ} \mathrm{W}$ & Neotropical region & Di Genaro, 2010 \\
\hline AS18 & Itaipu Reservoir, Brazil & $25.031^{\circ} \mathrm{S}, 54.379^{\circ} \mathrm{W}$ & Neotropical region & Velho et al., 2000 \\
\hline AS19 & Lake Blanca, Formosa, Argentina & $25.162^{\circ} \mathrm{S}, 58.143^{\circ} \mathrm{W}$ & Neotropical region & Paggi, 1979 \\
\hline AS 20 & Iraí Reservoir, Paraná, Brazil & $25.405^{\circ} \mathrm{S}, 49.096^{\circ} \mathrm{W}$ & Neotropical region & Ghidini et al., 2009 \\
\hline AS21 & Pozo Negro, Iguaçu River, Argentina & $25.602^{\circ} \mathrm{S}, 54.387^{\circ} \mathrm{W}$ & Neotropical region & José de Paggi, 2002 \\
\hline AS22 & Puerto Macuco, Iguaçu River, Argentina & $25.648^{\circ} \mathrm{S}, 54.458^{\circ} \mathrm{W}$ & Neotropical region & José de Paggi, 2002 \\
\hline AS23 & Lake in Formosa, Argentina & $26.170^{\circ} \mathrm{S}, 58.162^{\circ} \mathrm{W}$ & Neotropical region & Paggi, 1979 \\
\hline AS24 & El Cadillal Reservoir, Tucuman, Argentina & $26.608^{\circ} \mathrm{S}, 65.217^{\circ} \mathrm{W}$ & Neotropical region & Paggi, 1979 \\
\hline AS 25 & Itajai-Açu River, Santa Catarina, Brazil & $26.905^{\circ} \mathrm{S}, 49.017^{\circ} \mathrm{W}$ & Neotropical region & Serafim-Junior et al., 2006 \\
\hline AS26 & Lake near Itati, Corrientes, Argentina & $27.268^{\circ} \mathrm{S}, 58.251^{\circ} \mathrm{W}$ & Neotropical region & Paggi, 1979 \\
\hline AS27 & Rio Dulce, Santiago del Estero, Argentina & $27.504^{\circ} \mathrm{S}, 64.854^{\circ} \mathrm{W}$ & Neotropical region & Paggi, 1979 \\
\hline AS28 & Río Hondo Res., Santiago del Estero, Argentina & $27.522^{\circ} \mathrm{S}, 64.888^{\circ} \mathrm{W}$ & Neotropical region & waterflea.org database \\
\hline AS 29 & Lake in Corrientes, Argentina & $28.536^{\circ} \mathrm{S}, 56.033^{\circ} \mathrm{W}$ & Neotropical region & Paggi, 1979 \\
\hline AS30 & Lake Guabiyú, Santa Fe, Argentina & $28.761^{\circ} \mathrm{S}, 59.149^{\circ} \mathrm{W}$ & Neotropical region & Paggi, 1979 \\
\hline AS31 & Lake Itapeva, Rio Grande do Sul, Brasil & $29.488^{\circ} \mathrm{S}, 49.912^{\circ} \mathrm{W}$ & Neotropical region & Cardoso and Motta Marques, 2004 \\
\hline AS32 & Ditch near La Gallareta, Santa Fe, Argentina & $29.585^{\circ} \mathrm{S}, 60.384^{\circ} \mathrm{W}$ & Neotropical region & Paggi, 1979 \\
\hline AS33 & Pond at São Simão, Rio Grande do Sul, Brazil & $30.952^{\circ} \mathrm{S}, 50.708^{\circ} \mathrm{W}$ & Neotropical region & present study \\
\hline AS34 & Salto Grande Reservoir, Entre Rios, Argentina & $31.116^{\circ} \mathrm{S}, 58.050^{\circ} \mathrm{W}$ & Neotropical region & José de Paggi, 2002 \\
\hline AS35 & La Virgen Stream, Entre Rios, Argentina & $31.250^{\circ} \mathrm{S}, 57.917^{\circ} \mathrm{W}$ & Neotropical region & José de Paggi, 2002 \\
\hline AS36 & Lake Paiva, Santa Fe, Argentina & $31.275^{\circ} \mathrm{S}, 60.618^{\circ} \mathrm{W}$ & Neotropical region & Paggi, 1979 \\
\hline AS37 & San Roque Reservoir, Cordoba, Argentina & $31.370^{\circ} \mathrm{S}, 64.462^{\circ} \mathrm{W}$ & Neotropical region & Paggi, 1979 \\
\hline AS38 & Lake near Santo Tomé, Argentina & $31.668^{\circ} \mathrm{S}, 60.768^{\circ} \mathrm{W}$ & Neotropical region & Paggi, 1979 \\
\hline AS39 & Paraná River, Santa Fe, Argentina & $31.715^{\circ} \mathrm{S}, 60.516^{\circ} \mathrm{W}$ & Neotropical region & Paggi, 1979 \\
\hline AS40 & Los Mollinos Reservoir, Cordoba, Argentina & $31.842^{\circ} \mathrm{S}, 64.528^{\circ} \mathrm{W}$ & Neotropical region & Paggi, 1979; waterflea.org database \\
\hline AS41 & Cordoba Reservoir, Argentina & $32.179^{\circ} \mathrm{S}, 64.405^{\circ} \mathrm{W}$ & Neotropical region & waterflea.org database \\
\hline AS42 & Río Tercero Reservoir, Cordoba, Argentina & $32.213^{\circ} \mathrm{S}, 64.478^{\circ} \mathrm{W}$ & Neotropical region & Paggi, 1979, Escalante, 1988 \\
\hline AS43 & Paraná River, Buenos Ayres, Argentina & $34.303^{\circ} \mathrm{S}, 58.515^{\circ} \mathrm{W}$ & Neotropical region & Paggi, 1979 \\
\hline AS44 & Stream near Colonia, Uruguay & $34.457^{\circ} \mathrm{S}, 57.791^{\circ} \mathrm{W}$ & Neotropical region & Paggi, 1979 \\
\hline AS45 & Lake Ton-Ton, Uruguay & $34.851^{\circ} \mathrm{S}, 56.033^{\circ} \mathrm{W}$ & Neotropical region & Conde and Sommaruga, 1998 \\
\hline AS46 & Lake Don Tomás, La Pampa, Argentina & $36.622^{\circ} \mathrm{S}, 64.314^{\circ} \mathrm{W}$ & Neotropical region & Echaniz et al., 2008 \\
\hline AS47 & Lake Los Padres, Buenos Ayres, Argentina & $37.936^{\circ} \mathrm{S}, 57.731^{\circ} \mathrm{W}$ & Neotropical region & González-Sagrario and Balseiro, 2010 \\
\hline AS48 & Valle Fértil Reservoir, San Juan, Argentina & $30.634^{\circ} \mathrm{S}, 67.483^{\circ} \mathrm{W}$ & Andean region & Paggi, 1979 \\
\hline AS49 & Ameghino Reservoir, Chubut, Argentina & $43.792^{\circ} \mathrm{S}, 66.451^{\circ} \mathrm{W}$ & Andean region & Menu-Marque and Marinoni, 1986 \\
\hline AS50 & Lake Musters, Chubut, Argentina & $45.419^{\circ} \mathrm{S}, 69.177^{\circ} \mathrm{W}$ & Andean region & Menu-Marque and Marinoni, 1986 \\
\hline AS51 & Lake Colhue Huapi, Chubut, Argentina & $45.497^{\circ} \mathrm{S}, 68.767^{\circ} \mathrm{W}$ & Andean region & Menu-Marque and Marinoni, 1986 \\
\hline
\end{tabular}




\section{Material And Methods}

Occurrence records of $B$. huaronensis were obtained from literature and internet databases (Tab. 1). Two original records from Brazil were also included: a pond at São Simão Beach, Mostardas, Rio Grande do Sul state, $14 \mathrm{~m}$ a.s.1 (col. LMAEL, Jan.01.2002) and Lake Paranoá, Brasília, Federal District, c. 1,000m a.s.l (col. LMAEL, Feb.19.2012). When literature did not provide geographical coordinates, they were obtained from Google Earth, and only verifiable locations were included in the analysis.

The niche differentiation among $B$. buaronensis populations was investigated by conducting a principal components analysis (PCA), which also was used to identify climatic variables potentially important in the geographic distribution. The abiotic variables (19 climate and one topographic) were obtained from the WorldClim database (http://www.worldclim.org/) at 5 arcminutes resolution. The "extract value by point" function in DIVA 7.5.0 (Hijmans et al., 2001) was used to obtain the climate and altitude data for each locality.

Before conducting the PCA, a correlation matrix among all variables was constructed; this allowed the degree of multicollinearity in our dataset to be minimized by removing highly correlated variables $(r>0.8)$. Using this criterion, 12 variableswere removed from the initial dataset, and the PCA included the following eight variables: altitude, annual mean temperature, mean diurnal range, temperature seasonality, mean temperature of driest quarter, annual precipitation, precipitation of wettest quarter, and precipitation of driest quarter. The data were $\log 10$-transformed to standardize data for PCA. Statistics were performed using PAST (Hammer et al., 2001).

To better explore the possible aggregation of occurrence records, these were classified by biogeographic regions and transition zones (Tab. 1), following Morrone's criteria (2006).

\section{Results}

The data collected in the present study indicated that $B$. huaronensis is reported from 55 localities in South and North America (Tab. 1 ), ranging about $45^{\circ} \mathrm{S}$ to $35^{\circ} \mathrm{N}$.

In the multivariate analysis, the first and second principal components explained 44.9 and $28.1 \%$ of the overall variance, respectively. The climatic variables most associated with the distribution of occurrence records along axis 1 of the PCA diagram were annual mean temperature, precipitation of driest quarter, and annual precipitation (Tab. 2). Altitude had the strongest negative relation with axis 1. For axis 2 , the most related variables were temperature seasonality and precipitation of wettest quarter.

The ordination of occurrence records in the PCA diagram (Fig. 1) showed that populations from the biogeographic regions aggregate in three groups. The first group was represented by the records from South American and Mexican transition zones, including Lake Huaron (AS01), the type locality. The second one was formed by Neotropical populations. Nevertheless, there is an overlapping area between groups 1 and 2, represented by records AS24, AS27, AS28, AS37, AS40, AS41, and AS42 (Fig. 1; for exact localities, see Tab. 1). Finally, the third group aggregated the populations from Andean and Nearctic regions. One of the Neotropical records, from Lake Paranoá (AS08), was placed outside of the $90 \%$ density ellipses.

Table 2. PC1 and PC2 loadings from principal components analysis of environmental variables for populations of Bosmina huaronensis.

\begin{tabular}{lll}
\hline $\begin{array}{l}\text { Environmental variable (log- } \\
\text { transformed) }\end{array}$ & PCA 1 & PCA 2 \\
\hline Altitude & -0.7110 & 0.5093 \\
Annual Mean Temperature & 0.7648 & -0.3033 \\
Mean Diurnal Range & -0.6719 & 0.0910 \\
Temperature Seasonality & 0.0904 & -0.8838 \\
Mean Temperature of Driest & 0.6997 & -0.3066 \\
Quarter & & \\
Annual Precipitation & 0.7493 & 0.6217 \\
Precipitation of Wettest Quarter & 0.5206 & 0.7871 \\
Precipitation of Driest Quarter & 0.8502 & 0.0872 \\
\hline
\end{tabular}




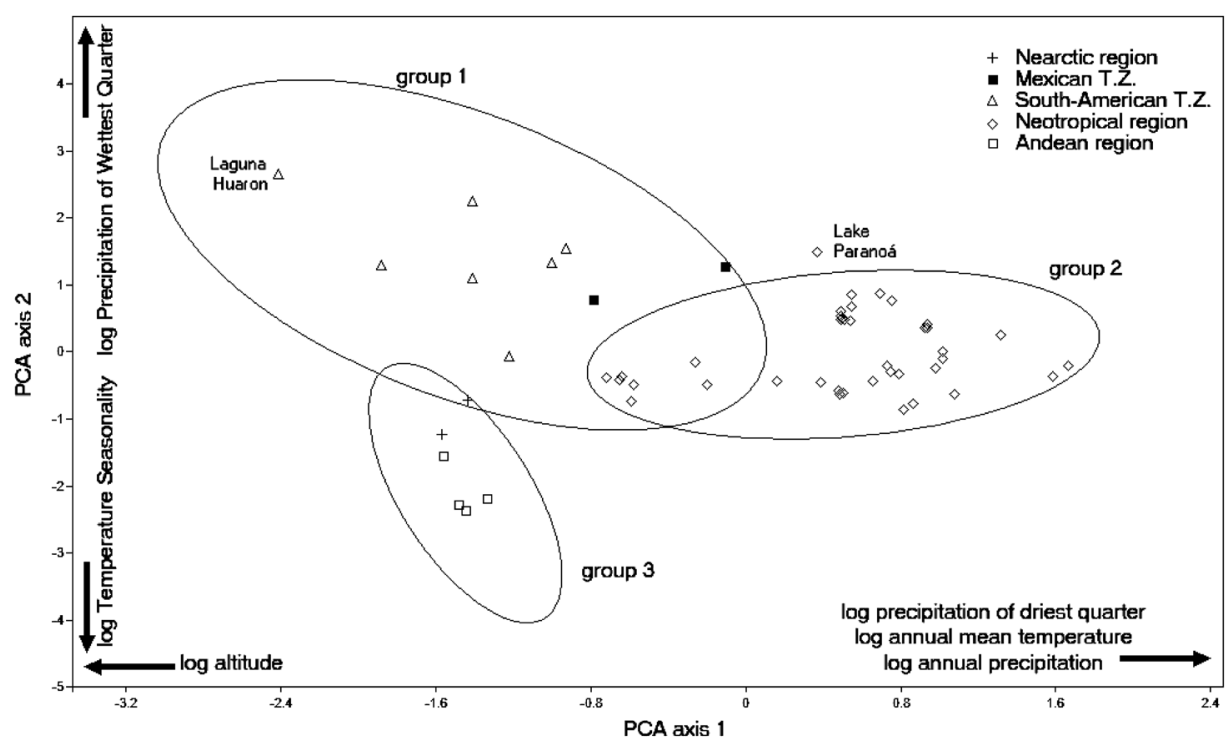

Figure 1. Principal component analysis (PCA) of environmental variables and geographic distributions of Bosmina huaronensis, with $90 \%$ density ellipses. The first component explains $44.9 \%$ of the variation and the second component $28.1 \%$. T.Z means transition zones.

\section{Discussion}

According to the surveyed records, B. huaronensis has a wide distribution range, including tropical and temperate zones of the American continent, from both hemispheres. In its range, this species occurs in a variety of water bodies, located at different altitudes and under diverse climate regimes.

The current distribution of species results from the interaction of large spatio-temporal processes (e.g. speciation, dispersal, climatic and geographic developments) and small-scale processes (e.g. competition, predation, local disturbances). The former processes act on a regional scale and govern species availability, but the local processes act as definite filters (Winkler and Kampichler, 2000).

The present study investigated $B$. huaronensis distribution only on regional approach, once only climatic and geographic aspects were considered. To better understand the processes acting on this species local distribution, it is also important to consider limnological variables and aspects of zooplankton community structure. However, this approach was outside the scope of this paper.

Despite this limitation, based on altitude and climate variables considered here, the occurrence localities of $B$. huaronensis were gathered into three groups (Figure 1). Group one represents the tropical high-altitude water bodies, located in the Central Andes and Central
Mexico. Populations of $B$. huaronensis in these regions occur at low annual mean temperature, temperature seasonality, and precipitation, which is concentrated in the wettest quarter. As the type locality belongs to this group, this climatic niche should be considered the most typical for the species.

The second group, represented by Neotropical records, corresponds to localities in tropical and subtropical lowlands (below $1,000 \mathrm{~m}$ a.s.l.). The climate niche of this group is characterized by low temperature seasonality and high annual mean temperatures and precipitation in the wettest quarter. The overlapping area between groups 1 and 2 corresponds to localities on the eastern side of the Andes, with lower precipitation in the driest quarter. It could represent a transitional niche between the former two groups, but, alternatively, it could mean that the Morrone regions and transition zones are not the best criterion under which to investigate $B$. huaronensis distribution.

High temperature seasonality and low annual mean temperature and precipitation characterize the occurrence records of the third group, located in temperate zones of both hemispheres.

As presented here, $B$. huaronensis populations were found under different climate regimes, supporting the idea that the dominant clones in each one occupy a different ecological 
niche. Many authors have showed clones of cladoceran species differing with regard to their physiological, reproductive, behavioral, and ecological traits (e.g. Reede and Ringelberg, 1995; Dodson et al., 1997; Innes and Singleton, 2000; Michels and De Meester, 2004; Forasacco \& Fontvieille, 2010; Lehto and Haag, 2010). Such differences, therefore, allow the occupation of different niches and enable the dominance of certain clones subjected to a particular climate regime.

Nevertheless, the possibility should not be excluded that these groups of populations could represent a complex of species. In recent years, new cladoceran species have been recognized as deep morphological and genetic comparisons between populations from different regions were conducted (e.g. De Melo and Hebert, 1994; Kappes and Sinsch, 2002; Nilssen et al., 2007; Elías-Gutiérrez and Valdez-Moreno, 2008; Belyaeva and Taylor, 2009; Kotov et al., 2009; Sinev and Elmoor-Loureiro, 2010; Van Damme et al., 2011). Therefore, B. huaronensis populations should be compared in their morphology, genetics and ecology in order to access their taxonomic status.

In particular, the population from Lake Paranoá should be better investigated. For about 30 years, the planktonic community of Lake Paranoá has been studied, and this species has never been reported before (ElmoorLoureiro et al., 2004; Mendonça-Galvão, 2005; Batista, 2007; see Padovesi-Fonseca et al., 2001 for previous records). Additionally, it represents the first record from Central Brazil (ElmoorLoureiro, 2000) and, in general morphology, the individuals do not differ from the species description (Paggi, 1979). However, at a similar latitude $\left(11^{\circ}\right.$ to $\left.17^{\circ} \mathrm{S}\right), B$. huaronensis had previously been reported only above $3,000 \mathrm{~m}$ a.s.l. (Delachaux, 1918; Uéno, 1967; Paggi, 1979; Valdivia-Villar, 1988; Coronel et al., 2007), while Lake Paranoá is located at about $1,000 \mathrm{~m}$ a.s.l. Such geographic uniqueness corresponds to a particular climate (Köppen's Aw, tropical savanna climate, with well defined wet and dry seasons), which is reflected in the PCA diagram, where the Lake Paranoá record is located outside of the $90 \%$ density ellipses (Figure 1). Although the possibility that this result arises from gaps in sampling effort cannot be discarded, a more detailed morphological comparison between Lake Paranoá and the typical population is recommended.

The present paper showed that B. huaronensis has a wide distribution in the Americas and that its populations occupy three different climate niches: tropical at high altitudes, tropical and subtropical in lowlands, and temperate. Comparative morphological, genetic, and ecological studies are needed to evaluate the taxonomic status of these population groups.

\section{REFERENCES}

Angelini, R.; Bini, L.M. and Starling, F.L.R.M. 2008. Efeitos de diferentes intervençóes no processo de eutrofizaçáo do lago Paranoá (Brasília - DF). Oecologia Brasiliensis, 12(3): 564-571.

Batista, C.A. 2007. Comunidade zooplanctônica e qualidade da água no Lago Paranoá, Brasília-DF. Universidade de Brasília, Brasilia, Master's Dissertation. 101p. [Unpublished]. Available at http://www.pgecl.unb.br/ index.php?option=com_contentandview $=$ articleandid $=82 \mathrm{a}$ ndItemid $=35$. Accessed on 28 May 2012.

Batista, T.A. and Gurgel-Gonçalves, R. 2009. Ecological niche modeling and differentiation between Rhodnius neglectus Lent, 1954 and Rhodnius nasutus Stål, 1859 (Hemiptera: Reduviidae: Triatominae) in Brazil. Memórias do Instituto Oswaldo Cruz, 104(8): 1165-1170.

Belyaeva, M. and Taylor, D.J. 2009. Cryptic species within the Chydorus sphaericus species complex (Crustacea: Cladocera) revealed by molecular markers and sexual stage morphology. Molecular Phylogenetics and Evolution, 50(3): 534-546.

Cardoso, L.S. and Motta Marques, D. 2004. Structure of the zooplankton community in a subtropical shallow lake (Itapeva Lake - South of Brazil) and its relationship to hydrodynamic aspects. Hydrobiologia, 518: 123-134.

Conde, D. and Sommaruga, R. 1998. A review of the state of Limnology in Uruguay. p. 1-31. In: J. Gopal and R. Wetzel (eds). Limnology in Developing Countries II. International Society of Limnology SIL/LDC, Stuttgart.

Coronel, J.S.; Declerck, S. and Brendonck, L. 2007. Highaltitude peatland temporary pools in Bolivia house a high cladoceran diversity. Wetlands, 27(4): 1166-1174.

Delachaux, T. 1919. Cladocères des Andes Péruviennes. Bulletin de la Société Neuchâteloise des Sciences Naturelles, 44: 18-38.

DiGenaro, A.C. 2010. Mudanças na comunidadezooplanctônica após remoção de macrófitas em um lago urbano (Lago das Garças, PEFI, SP). Instituto de Pesca, São Paulo, Brazil, Master's Dissertation. [Unpublished]. Available at $\mathrm{ftp}: / / \mathrm{ftp}$. sp.gov.br/ftppesca/DissertaArianeDiGenaro.pdf . Accessed on 14 June 2012.

Dodson, S.I.; Ryan, S.; Tollrian, R. and Lampert, W. 1997. Individual swimming behavior of Daphnia: effects of food, light and container size in four clones. Journal of Plankton Research, 19(10): 1537-1552.

Echaniz, S.A.; Vignatti, A.M. and Bunino, P.C. 2008. El zooplancton de un lago somero hipereutrófico de la región central de Argentina: cambios después de una década. Biota Neotropica, 8(4): 63-71.

Elías-Gutiérrez, M.and Valdez-Moreno, M. 2008. A new cryptic species of Leberis Smirnov, 1989 (Crustacea, Cladocera, Chydoridae) from the Mexican semi-desert region, highlighted by DNA barcoding. Hydrobiologia, 360: 63-73.

Elmoor-Loureiro, L.M.A. 2000. Brazilian cladoceran studies: where do we stand? Nauplius, 8(2): 117-131.

Elmoor-Loureiro, L.M.A. Mendonça-Galvão, L. and PadovesiFonseca, C. 2004. New Cladoceran records from lake Paranoá, Central Brazil. Brazilian Journal of Biology, 63: 415-422. 
Escalante, A. H. 1988. Cladóceros del embalse Río Tercero (Provincia de Córdoba, Argentina). Anales del Instituto Ciencias del Mar y Limnologia, Universidad Nacional Autónoma de México, 15(1): 41-54.

Forasacco, E. and Fontvieille, D. 2010. Evaluation of respiration parameters in a few generations and clones of Simocephalus vetulus (Crustacea, Cladocera) under controlled conditions. Hydrobiologia, 643: 77-83.

Ghidini, A.R.; Serafim-Júnior, M.; Perbiche-Neves, G. and Brito, L. 2009. Distribution of planktonic cladocerans (Crustacea: Branchiopoda) of a shallow eutrophic reservoir (Paraná State, Brazil). Pan-American Journal of Aquatic Sciences, 4(3): 294-305.

Giannini, T.C.; Takahasi, A.; Medeiros, M.C.M.P.; Saraiva, A.M. and Alves-dos-Santos, I.. 2011. Ecological niche modeling and principal component analysis of Krameria Loefl. (Krameriaceae). Journal of Arid Environments, 75: 870-872.

GMS-DBD, 2012 - The Global Mirror System of DNA Barcode Data. Available at http://nz.boldmirror.net/index.php/ search/. Accessed on 28 June 2012.

González-Sagrario, M.A. and Balseiro, E. 2010. The role of macroinvertebrates and fish in regulating the provision by macrophytes of refugia for zooplankton in a warm temperate shallow lake. Freshwater Biology, 55: 2153-2166.

Hammer, Ø.; Harper, D.A.T. and Ryan, P.D. 2001. PAST: Paleontological statistics software package for education and data analysis. Palaeontologia Electronica, 4(1): 9pp. Available at http://palaeo-electronica.org/2001_1/past/issue1_01. htm. Accessed on 25 August 2011.

Hijmans, R.J.; Guarino, L.; Cruz, M. and E. Rojas. 2001. Computer tools for spatial analysis of plant genetic resources data: 1. DIVA-GIS. Plant Genetic Resources Newsletter, 127: 15-19.

Hutchinson, G.E. 1957. Concluding remarks. Cold Spring Harbor Symposia on Quantitative Biology, 22: 415-427.

Ibarra-Cerdeña, C. N.; Sánchez-Cordero, V.; Peterson, A.T. and Ramsey, J.M. 2009. Ecology of North American Triatominae. Acta Tropica, 110: 178-186.

Innes, D.J. and Singleton, D.R. 2000. Variation in allocation to sexual and asexual reproduction among clones of cyclically parthenogenetic Daphinia pulex (Crustacea: Cladocera). Biological Journal of the Linnean Society, 71: 771-787.

Janžekovič, F. and Novak, T. 2012. PCA for Analyze Ecological Niches. p. 127-142. In: P. Sanguansat. Principal Component Analysis - Multidisciplinary Applications. InTech Books. Available at http://www.intechopen.com/books/principalcomponent-analysis-multidisciplinaryapplications/pca-apowerful-method-to-analyze-the-ecological-niche. Accessed on 17 December 2012.

José de Paggi, S. 2002. New data on the distribution of Kellicottia bostoniensis (Rousselet, 1908) (Rotifera: Monogononta: Brachionidae): Its presence in Argentina. Zoologischer Anzeiger, 241: 363-368.

Kamilar, J.M. and Muldoon, K.M. 2010. The climatic niche diversity of Malagasy Primates: A Phylogenetic Perspective. PLoS ONE, 5(6): e11073. DOI:10.1371/ journal. pone.0011073.

Kappes, H. and Sinsch, U. 2002. Morphological variation in Bosmina longirostris (Crustacea: Cladocera): consequence of cyclomorphosis or indication of cryptic species? Journal of Zoological Systematics and Evolutionary Research, 40(3): 113122.

Knouft, J.H.; Losos, J.B.; Glor, R.E. and Kolbe, J.J. 2006. Phylogenetic analysis of the evolution of the niche in lizards of the Anolis sagrei group. Ecology 87(7, Supp.): S29-S38.

Kotov, A.A.; Ishida, S. and Taylor, D.J. 2009. Revision of the genus Bosmina Baird, 1845 (Cladocera: Bosminidae), based on evidence from male morphological characters and molecular phylogenies. Zoological Journal of the Linnean Society, 156: 1-51.

Lehto, M.P. and Haag, C.R. 2010. Ecological differentiation between coexisting sexual and asexual strains of Daphnia pulex. Journal of Animal Ecology, 79: 1241-1250.

Mendonça-Galvăo, L. 2005. A comunidade planctônica e o processo de restauraçáo do Lago Paranoá, DF. Universidade de Brasília, Brasilia, Ph.D. Thesis, 251p. [Unpublished].
Michels, E. and De Meester, L. 2004. Inter-clonal variation in phototactic behaviour and key life-history traits in a metapopulation of the cyclical parthenogen Daphnia ambigua: the effect of fish kairomones. Hydrobiologia, 522: 221-233.

Menu-Marque, S.A. and Marinone, M.C. 1986. El zooplancton de seis lagos del Chubut (Argentina) y sus probables relaciones con la ictiofauna y algunos factores ambientales. COPESCAL Documento Técnico, 4: 90-114.

Morrone, J.J. 2006. Biogeographic areas and transition zones of Latin America and the Caribbean Islands based on panbiogeographic and cladistic analyses of the entomofauna. Annual Review of Entomology, 51: 467-494.

Nilssen, J.P.; Hobaek, A.; Petrusek A. and Skage, M. 2007. Restoring Daphnia lacustris G.O. Sars, 1862 (Crustacea, Anomopoda): a cryptic species in the Daphnia longispina group. Hydrobiologia, 594: 5-17.

Padovesi-Fonseca, C.; Mendonça-Galvão, L.; Pereira, D.F.; Philomeno, M.G. and Pereira, D.L. 2001. O zooplâncton do Lago Paranoá. p. 115-117. In: F.O. Fonseca (ed.). Olhares sobre o Lago Paranoá. Brasília, Secretaria do Meio Ambiente e Recursos Hídricos do DF.

Paggi, J.C. 1979. Revision de las especies argentinas del género Bosmina Baird agrupadas en el subgenero Neobosmina Lieder (Crustacea: Cladocera). Acta Zoologica Lilloana, 35: 137-162.

Reede, T. and Ringelberg, J. 1995. The influence of a fish exudante on two clones of the hybrid Daphnia galeata $\mathrm{x}$ hyaline. Hydrobiologia, 307: 207-212.

Rocha, O.; Santos-Wisniewski, M.J. and Matsumura-Tundisi, T. 2011. Checklist de Cladocera de água doce do Estado de Sáo Paulo. Biota Neotropica, 11(1a): http://www. biotaneotropica.org.br/v11n1a/en/abstract?inventory+bn0 271101a2011. - ISSN 1676-0603.

Schnitzler, J.; Graham, C.H.; Dormann, C.F.; Schiffers, K. and Linder, H.P. 2012. Climatic niche evolution and species diversification in the Cape flora, South Africa. Journal of Biogeography, 39: 2201-2211.

Serafim-Júnior, M.; Perbiche-Neves, G.; Brito, L. and Ghidini, A.R.. 2006. Zooplâncton do Rio Itajaí-Açú a jusante da cidade de Blumenau, Santa Catarina, Brasil. Estudos de Biologia, 28(65): 41-50.

Sinev, A.Y and Elmoor-Loureiro, L.M.A. 2010. Three new species of chydorid cladocerans of subfamily Aloninae (Branchipoda: Anomopoda: Chydoridae) from Brazil. Zootaxa, 2390: 1-25.

Uéno, M. 1967. Zooplankton of lake Titicaca on the Bolivian side. Hydrobiologia, 29: 547-568.

Valdivia-Villar, R.S. 1988. Lista de cladóceros dulceacuícolas del Perú. Amazoniana, 10(3): 283-297.

Van Damme, K.; Sinev, A.Y. and Dumont, H.J. 2011. Separation of Anthalona gen.n. from Alona Baird, 1843 (Branchiopoda: Cladocera: Anomopoda): morphology and evolution of scraping stenothermic alonines. Zootaxa, 1960: 1-44.

Velho, L.F.M.; Lansac-Tôha, F.A. and Bonecker, C.C. 2000. New record of planktonic cladoceran to the upper Paraná River, Brazil: Bosmina huaroensis Delachaux, 1918. Revista Brasileira de Biologia, 60(4): 633-636.

Waterflea, 2012. Waterflea.org database. Available at http:// www.waterflea.org/waterflea.org/Database.html. Accessed on 28 June 2012.

Winkler, H. and Kampichler, C. 2000. Local and regional species richness in communities of surface-dwelling grassland Collembola: indication of species saturation. Ecography, 23: 385-392.

Zanata, L.H. 2005. Distribuiçáo das populaçóes de Cladocera (classe Crustacea) nos reservatórios do Médio e Baixo Rio Tietê: uma análise espacial e temporal. Universidade de São Paulo, Escola de Engenharia de São Carlos. Ph.D. Thesis, 282p. [Unpublished]. Available at http://www.teses.usp. br/teses/disponiveis/18/18139/tde-20022006-180205/ en.php. Accessed on 18 October 2012.

Submitted 13 February 2013 Accepted 16 September 2013 